\title{
Comparison of grading systems of mucoepidermoid carcinoma and the impact on patient survival
}

Jayasooriya $P R^{l}$, Karunathilake $P R C L^{l}$, Siriwardena BSMS $S^{l}$, Amaratunga EAPD ${ }^{l}$, Attygalla $A M^{2}$

\begin{abstract}
Objective: To grade MEC using the criteria of the Armed forces Institute of Pathology (AFIP), Brandwein point based system and Modified Healey qualitative analytic system and correlate the survival data with the grading obtained for each patient.
\end{abstract}

Method: Haematoxylin and eosin stained slides of 34 patients with MEC were used to grade the tumours according to the criteria specified in the three grading systems. Survival period in months and the outcome including if the patient had died due to disease or whether the patient is living with or without disease was obtained by sending a questionnaire to the patients/relatives of the patient.

Results: Statistically significant higher recurrence and poor survival rates could be observed in high grade MECs compared to low/intermediate grade tumours when MECs were graded according to AFIP (Recurrence rate $-p=0.0036$, survival $-p=0.0067$ ) and Modified Healey (Recurrence rate $-\mathrm{p}=0.031$, survival $-\mathrm{p}=0.0067$ ) system. However, no statistically significant differences could be demonstrated when the tumours were graded according to Brandwein classification ( $\mathrm{p}>0.05)$.

Conclusion: The histopathological grade carries a high prognostic significance, when MECs are graded according to AFIP and Modified Healey classifications, while Brandwein system was unsuitable to predict the survival and prognosis of patients.

Key words: Mucoepidermoid carcinoma, histopathological grading, survival

\section{Introduction}

Mucoepidermoid carcinoma (MEC) is a malignant epithelial neoplasm characterized by proliferation of mucous, intermediate and epidermoid cells of varying proportions, with or without clear cells. MEC accounts for approximately $10-15 \%$ of all salivary neoplasms and $30 \%$ of malignant salivary carcinomas $(1,2,3)$. MECs display a variety of biological behaviour ranging from aggressive to non aggressive $(2,3,4,5)$. Over the years several systems

${ }^{I}$ Department of Oral Pathology, Faculty of Dental Sciences, University of Peradeniya, Peradeniya, Sri Lanka.

${ }^{2}$ Department of Oral Maxillofacial Surgery, Faculty of Dental Sciences, University of Peradeniya, Peradeniya, Sri Lanka.

Correspondence: Jayasooriya PR, Department of Oral Pathology, Faculty of Dental Sciences, University of Peradeniya,Peradeniya,Sri Lanka.e-mail: primalij@yahoo.com 
including, that of the AFIP and Brandwein point based grading systems and Modified Healey qualitative analytic system, were developed to grade this neoplasm $(5,6,7,8,9)$. The AFIP grading system (which is the most widely used system) has been shown to be valuable in both management and predicting the prognosis of MEC (10). However, this grading system cannot be considered as a gold standard, as some tumours have been shown to behave in an unpredictable manner, not corresponding to the behaviour expected for a given grade $(3,11)$. Although, there are numerous studies in other countries, to support the value of each grading system (2,5-8), similar studies are very few in Asia, including Sri Lanka, due to the lack of follow up data.

\section{Objective}

To grade MEC using the criteria of the Armed forces Institute of Pathology (AFIP), Brandwein point based system and Modified Healey qualitative analytic system and correlate the survival data with the grade and identify the most suitable system that predicts survival rate of patients with MEC, for use in Sri Lanka.

\section{Materials and Methods}

The demographic data including, age at diagnosis, sex, site of the lesion and management details were obtained from the records of 34 patients diagnosed with MEC. Follow up and survival data were obtained using a questionnaire prepared in two languages and sent to the patient/relative by mail. Haematoxylin and Eosin stained slides were reviewed and graded using the AFIP, Brandwein and
Modified Healey grading systems.

The AFIP grading system, based on intra-cystic component of less than $20 \%$, neural invasion, necrosis, four or more mitotic figures per ten high-power fields and cellular anaplasia, allocates a point value of 2,2,3,3 and 4 for each characteristic respectively. The total value obtained for each tumour is considered as the point score, which is used to divide the MECs in to three types, namely low grade 0-4 points, intermediate grade 5-7 points and high grade $>7$ points $(5,6)$. Brandwein grading system, is based on the evaluation of eight features, namely intra-cystic component of $<25 \%$, presence of small nests and islands at the advancing front, pronounced nuclear atypia, lymphatic and or vascular invasion, bony invasion, more than 4 mitoses per 10HPF, perineural spread and necrosis, allocates a point value of 2,2,2,3,3,3,3 and 3 for each feature. This results in the division of MECs in to three grades, namely Grade I- 0 point, Grade II -2-3 points and Grade III-4 or more points (7).

The Modified Healey grading system is a purely qualitative grading system which divides MECs in to three grades, namely Grade I (low grade), Grade II (intermediate grade) and Grade III (high grade). A low grade tumour is characterized by the presence of macro cysts and micro cysts, with areas of transition from adjacent excretory ducts, proliferation of daughter cysts from large cysts, equal proportion of differentiated mucous and epidermoid cells, minimum to absent pleomorphism and rare mitosis, often circumscribed with broad infiltration of tissues and extravas- 
ated mucin pools. A grade II or intermediate grade $\mathrm{MEC}$, is characterized by the presence of solid nests of cells with few micro cysts and no macro cysts, predominantly intermediate cells with or without epidermoid cells and sparse mucous cells, mild to moderate pleomorphism with identifiable nucleoli and occasional mitosis, well defined non-circumscript infiltration of tissues, fibrosis separating cells nests with chronic inflammation at periphery of the tumour. A grade III or a high grade MEC is characterized by predominantly solid nests of tumour cells with marked pleomorphism, prominent nucleoli, and frequent mitosis. Definite invasion of soft tissues, desmoplasia and less prominent chronic inflammation being other features $(8,9)$. Statistical analysis was performed using SPSS 13.0 soft ware for windows using Chi square test. Kaplan Meier method was used to plot the survival curves for the three grades of MEC, obtained for each of the grading system.

\section{Results}

The clinicopathological characteristics and survival data of the 34 patients are shown in table 1 and 2. The comparison of the three

\begin{tabular}{|c|c|c|c|c|c|}
\hline No & $\begin{array}{l}\text { Age } \\
/ \text { Sex }\end{array}$ & Site & Treatment & $\begin{array}{l}\text { Status of } \\
\text { excision } \\
\text { margins }\end{array}$ & Survival status \\
\hline 1 & $60 \mathrm{M}$ & $\begin{array}{l}\text { Retromolar } \\
\text { region }\end{array}$ & Surgery & Clear & $\begin{array}{l}\text { Alive without } \\
\text { disease }\end{array}$ \\
\hline 2 & $65 \mathrm{M}$ & Tongue & Surgery & Involved & $\begin{array}{l}\text { Alive with } \\
\text { disease }\end{array}$ \\
\hline 3 & $64 \mathrm{~F}$ & $\begin{array}{l}\text { Retromolar } \\
\text { region }\end{array}$ & Surgery & Clear & $\begin{array}{l}\text { Alive with } \\
\text { disease }\end{array}$ \\
\hline 4 & $48 \mathrm{M}$ & Palate & Surgery & Clear & $\begin{array}{l}\text { Alive without } \\
\text { disease }\end{array}$ \\
\hline 5 & $52 \mathrm{~F}$ & Buccal mucosa & Radiotherapy & N/A & $\begin{array}{l}\text { Dead due to } \\
\text { disease }\end{array}$ \\
\hline 6 & $60 \mathrm{M}$ & $\begin{array}{l}\text { Retromolar } \\
\text { region }\end{array}$ & Radiotherapy & N/A & $\begin{array}{l}\text { Alive with } \\
\text { disease }\end{array}$ \\
\hline 7 & $15 \mathrm{~F}$ & Parotid & Surgery & Clear & $\begin{array}{l}\text { Alive without } \\
\text { disease }\end{array}$ \\
\hline 8 & $38 \mathrm{~F}$ & Palate & Surgery + Chemotherapy & Involved & $\begin{array}{l}\text { Alive with } \\
\text { disease }\end{array}$ \\
\hline 9 & $41 \mathrm{~F}$ & Parotid & Surgery+Radiotherapy & Involved & $\begin{array}{l}\text { Alive without } \\
\text { disease }\end{array}$ \\
\hline 10 & $45 \mathrm{~F}$ & Palate & Surgery & Clear & $\begin{array}{l}\text { Alive without } \\
\text { disease }\end{array}$ \\
\hline 11 & $54 \mathrm{M}$ & $\begin{array}{l}\text { Sub mandibular } \\
\text { gland }\end{array}$ & $\begin{array}{l}\text { Surgery+Radiotherapy } \\
\text { +chemotherapy }\end{array}$ & Involved & $\begin{array}{l}\text { Dead due to } \\
\text { disease }\end{array}$ \\
\hline 12 & $77 \mathrm{~F}$ & $\begin{array}{l}\text { Retromolar } \\
\text { region }\end{array}$ & Surgery & Clear & $\begin{array}{l}\text { Alive without } \\
\text { disease }\end{array}$ \\
\hline 13 & $45 \mathrm{~F}$ & $\begin{array}{l}\text { Sub lingual } \\
\text { gland }\end{array}$ & Surgery & Clear & $\begin{array}{l}\text { Alive without } \\
\text { disease }\end{array}$ \\
\hline
\end{tabular}




\begin{tabular}{|c|c|c|c|c|c|}
\hline 14 & $34 \mathrm{~F}$ & $\begin{array}{l}\text { Floor of the } \\
\text { mouth }\end{array}$ & Surgery+Chemotherapy & Involved & $\begin{array}{l}\text { Alive without } \\
\text { disease }\end{array}$ \\
\hline 15 & $42 \mathrm{~F}$ & Maxilla & Surgery+Radiotherapy & Involved & $\begin{array}{l}\text { Alive without } \\
\text { disease }\end{array}$ \\
\hline 16 & $51 \mathrm{M}$ & Parotid & Surgery+Radiotherapy & Clear & $\begin{array}{l}\text { Dead due to } \\
\text { disease }\end{array}$ \\
\hline 17 & $32 \mathrm{~F}$ & Parotid & Surgery+Radiotherapy & Clear & $\begin{array}{l}\text { Alive without } \\
\text { disease }\end{array}$ \\
\hline 18 & $71 \mathrm{M}$ & Tongue & Surgery & Clear & $\begin{array}{l}\text { Alive with } \\
\text { disease }\end{array}$ \\
\hline 19 & $40 \mathrm{~F}$ & Parotid & Surgery & Clear & $\begin{array}{l}\text { Alive without } \\
\text { disease }\end{array}$ \\
\hline 20 & $60 \mathrm{~F}$ & $\begin{array}{l}\text { Floor of the } \\
\text { mouth }\end{array}$ & Surgery+Radiotherapy & Clear & $\begin{array}{l}\text { Dead due to } \\
\text { disease }\end{array}$ \\
\hline 21 & $52 \mathrm{~F}$ & Palate & Surgery & Clear & $\begin{array}{l}\text { Alive without } \\
\text { disease }\end{array}$ \\
\hline 22 & $17 \mathrm{~F}$ & Parotid & Surgery & Clear & $\begin{array}{l}\text { Alive without } \\
\text { disease }\end{array}$ \\
\hline 23 & $65 \mathrm{M}$ & Tongue & Surgery & Clear & $\begin{array}{l}\text { Alive without } \\
\text { disease }\end{array}$ \\
\hline 24 & $42 \mathrm{~F}$ & Parotid & Surgery & Clear & $\begin{array}{l}\text { Alive without } \\
\text { disease }\end{array}$ \\
\hline 25 & $37 \mathrm{~F}$ & Buccal mucosa & Surgery & Clear & $\begin{array}{l}\text { Alive without } \\
\text { disease }\end{array}$ \\
\hline 26 & $15 \mathrm{~F}$ & Palate & Surgery & Clear & $\begin{array}{l}\text { Alive without } \\
\text { disease }\end{array}$ \\
\hline 27 & $28 \mathrm{~F}$ & Palate & Surgery & Clear & $\begin{array}{l}\text { Alive without } \\
\text { disease }\end{array}$ \\
\hline 28 & $18 \mathrm{M}$ & Lower lip & Surgery & Clear & $\begin{array}{l}\text { Alive without } \\
\text { disease }\end{array}$ \\
\hline 29 & $48 \mathrm{M}$ & Maxilla & Surgery+Radiotherapy & Involved & $\begin{array}{l}\text { Alive with } \\
\text { disease }\end{array}$ \\
\hline 30 & $22 \mathrm{~F}$ & Palate & Surgery & Clear & $\begin{array}{l}\text { Alive without } \\
\text { disease }\end{array}$ \\
\hline 31 & $36 \mathrm{~F}$ & Parotid & Surgery & Clear & $\begin{array}{l}\text { Alive without } \\
\text { disease }\end{array}$ \\
\hline 32 & $43 \mathrm{M}$ & Tongue & Surgery+Radiotherapy & Clear & $\begin{array}{l}\text { Dead due to } \\
\text { disease }\end{array}$ \\
\hline 33 & $27 \mathrm{M}$ & Maxilla & Surgery+Radiotherapy & Clear & $\begin{array}{l}\text { Alive without } \\
\text { disease }\end{array}$ \\
\hline 34 & $22 \mathrm{M}$ & Parotid & Surgery & Clear & $\begin{array}{l}\text { Alive without } \\
\text { disease }\end{array}$ \\
\hline
\end{tabular}

Table 1. Clinico pathological characteristics of the patients included in the study sample 


\begin{tabular}{|c|c|c|c|}
\hline \multirow{2}{*}{$\begin{array}{l}\text { Follow up period } \\
\text { in months }\end{array}$} & \multicolumn{3}{|c|}{ Status of survival } \\
\hline & Alive without disease & Alive wi & $\begin{array}{l}\text { Dead due to } \\
\text { disease }\end{array}$ \\
\hline Up to 12 months & $09(26.5)$ & $03(08.9)$ & $03(08.9)$ \\
\hline 13-35 months & $11(32.3)$ & $02(05.9)$ & $01(02.9)$ \\
\hline 36-59 months & $01(02.9)$ & $01(02.9)$ & 00 \\
\hline$>60$ months & $02(05.9)$ & 00 & $01(02.9)$ \\
\hline Total & $23(67.6)$ & $06(17.7)$ & $05(14.7)$ \\
\hline
\end{tabular}

Table 2. Survival data of the 34 patients with MEC

\begin{tabular}{|c|c|c|c|c|c|c|c|}
\hline & \multicolumn{2}{|c|}{$\begin{array}{l}\text { AFIP Grading } \\
\text { Low Intermediate High }\end{array}$} & \multicolumn{2}{|c|}{ Brandwein Grading } & \multicolumn{3}{|c|}{ Modified Healey Grading } \\
\hline $\begin{array}{l}\text { Age } \\
<50 \text { years } \\
>51 \text { years }\end{array}$ & $\begin{array}{lc}19 & 01 \\
(55.8) & (2.9) \\
02 & 00 \\
(5.9) & \end{array}$ & $\begin{array}{c}02 \\
(5.8) \\
06 \\
(17.6)\end{array}$ & $\begin{array}{lc}03 & 06 \\
(8.8) & (17.6) \\
02 & 01 \\
(5.8) & (2.9)\end{array}$ & $\begin{array}{c}13 \\
(38.2) \\
09 \\
(8.8)\end{array}$ & $\begin{array}{l}05 \\
(14.7) \\
03 \\
(8.8)\end{array}$ & $\begin{array}{c}14 \\
(41.2) \\
04 \\
(11.7)\end{array}$ & $\begin{array}{c}03 \\
(8.2) \\
05 \\
(14.7)\end{array}$ \\
\hline $\begin{array}{l}\text { Sex } \\
\text { Male } \\
\text { Female }\end{array}$ & $\begin{array}{lc}07 & 00 \\
(20.6) & \\
18 & 01 \\
(52.9) & (2.9)\end{array}$ & $\begin{array}{l}06 \\
(17.6) \\
02 \\
(5.8)\end{array}$ & $\begin{array}{ll}01 & 02 \\
(2.9) & (5.8) \\
04 & 05 \\
(11.8) & (14.7)\end{array}$ & $\begin{array}{l}10 \\
(29.4) \\
12 \\
(35.2)\end{array}$ & $\begin{array}{l}02 \\
(5.8) \\
6 \\
(17.6)\end{array}$ & $\begin{array}{c}05 \\
(14.7) \\
13 \\
(38.2)\end{array}$ & $\begin{array}{l}06 \\
(17.6) \\
02 \\
(5.8)\end{array}$ \\
\hline $\begin{array}{l}\text { Site } \\
\text { Major Salivary glands } \\
\text { Minor Salivary glands }\end{array}$ & $\begin{array}{ll}09 & 00 \\
(26.5) & \\
16 & 01 \\
(47.1) & (2.9)\end{array}$ & $\begin{array}{c}02 \\
(5.9) \\
06 \\
(17.6)\end{array}$ & $\begin{array}{ll}02 & 05 \\
(5.9) & (14.7) \\
03 & 02 \\
(8.8) & (5.9)\end{array}$ & $\begin{array}{l}04 \\
(11.8) \\
18 \\
(52.9)\end{array}$ & $\begin{array}{l}04 \\
(11.8) \\
04 \\
(11.8)\end{array}$ & $\begin{array}{l}05 \\
(14.7) \\
13 \\
(38.2)\end{array}$ & $\begin{array}{l}02 \\
(5.9) \\
06 \\
(17.6)\end{array}$ \\
\hline $\begin{array}{l}\text { Recurrences } \\
\text { Present } \\
\text { Absent }\end{array}$ & $\begin{array}{ll}04 & 00 \\
(11.8) & \\
21 & 01 \\
(61.8) & (2.9)\end{array}$ & $\begin{array}{l}06 \\
(17.6) \\
02 \\
(5.8)\end{array}$ & $\begin{array}{ll}04 & 02 \\
(11.8) & (5.8) \\
01 & 05 \\
(2.9) & (14.7)\end{array}$ & $\begin{array}{c}08 \\
(23.5) \\
14 \\
(41.2)\end{array}$ & $\begin{array}{l}02 \\
(5.9) \\
06 \\
(17.6)\end{array}$ & $\begin{array}{c}03 \\
(8.2) \\
15 \\
(44.1)\end{array}$ & $\begin{array}{l}06 \\
(17.6) \\
12 \\
(35.3)\end{array}$ \\
\hline $\begin{array}{l}\text { Outcome } \\
\text { Alive without disease } \\
\text { Alive with disease } \\
\text { Dead due to disease }\end{array}$ & $\begin{array}{lc}21 & 01 \\
(61.8) & (2.9) \\
03 & 00 \\
(8.8) & \\
01 & 00 \\
(2.9) & \end{array}$ & $\begin{array}{l}01 \\
(2.9) \\
03 \\
(8.8) \\
04 \\
(11.8)\end{array}$ & $\begin{array}{ll}04 & 05 \\
(11.8)(14.7) \\
01 & 02 \\
(2.9) & (5.8) \\
00 & 00\end{array}$ & $\begin{array}{l}14 \\
(41.2) \\
03 \\
(8.2) \\
05 \\
(14.7)\end{array}$ & $\begin{array}{l}06 \\
(17.6) \\
02 \\
(5.8) \\
00\end{array}$ & $\begin{array}{l}15 \\
(44.1) \\
02 \\
(5.8) \\
01 \\
(2.9)\end{array}$ & $\begin{array}{l}02 \\
(5.8) \\
02 \\
(5.8) \\
04 \\
(11.8)\end{array}$ \\
\hline
\end{tabular}

Table 3. Comparison of AFIP, Modified Healey and Brandwein grading obtained for MEC, outcome and clinico-pathological characteristics 
grading systems with the outcome and clinicopathological characteristics are in table 3 . The higher recurrence rate of high grade MECs compared to low/intermediate grade MEC, when grading was done by the AFIP $\mathrm{p}=0.0036$ and Modified Healey $\mathrm{p}=0.031$ systems, was statistically significant. However, no statistically significant difference was demonstrable when graded according to the Brandwein system $(p>0.05)$. Statistically significant relationship was present between the grade of MEC and survival rate when graded according to criteria given in the AFIP and Modified Healey system, as patients with high grade MEC showed significantly poor survival compared to patients with low/intermediate grade MEC $(p=0.0067)$. However, such difference was not seen when graded according to the Brandwein system. Kaplan Meir curves for disease specific survival for each category for all three systems are shown in figure $1 \mathrm{a}, \mathrm{b}$ and $\mathrm{c}$.

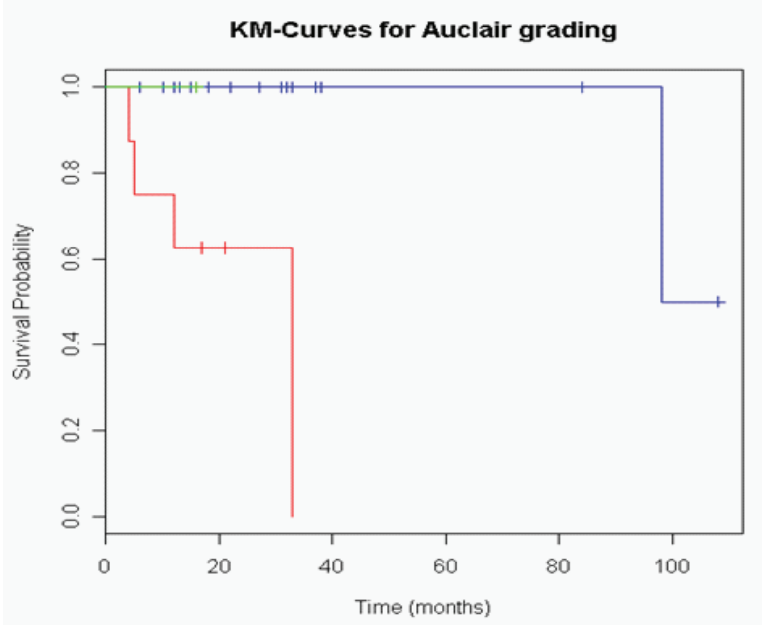

Fig 1a. AFIP grading, Fisher's exact test:

$\mathrm{P}$-Value $=0.0067420$

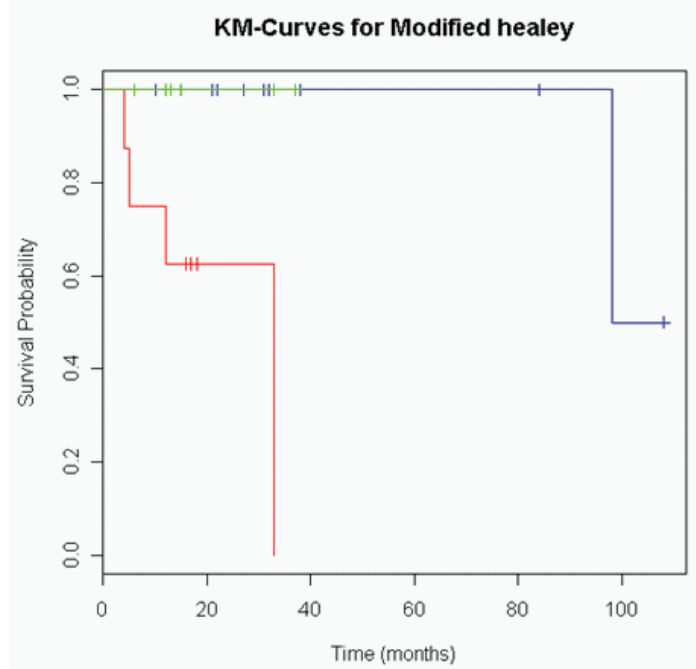

Fig 1b. Modified Healey grading, Fisher's exact test: $\mathrm{P}$-Value $=0.0067420$

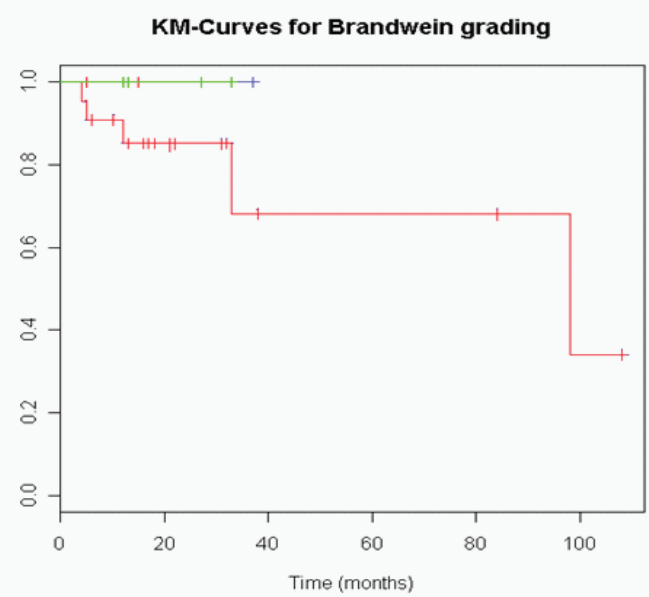

Fig 1c. Brandwein grading, Fisher's exact test: $\mathrm{P}$-Value $=0.131717$

\section{Discussion}

The grades obtained with the AFIP and Modified Healey system were shown to carry statistically significant correlation with patient survival, particularly with reference to low/intermediate vs. high grade MEC. In contrast, the Brandwein system did not show a statistically significant relationship between low/intermediate grade tumours vs. high grade tumours and 
patient survival. Lack of reproducibility of histopathological features may have contributed to the statistically non significant result obtained for the Brandwein grading in the present study compared to previous studies. Hence the grading obtained with the Brandwein system was not useful as a predictor of survival in the present group of patients. While the AFIP and Modified Healey classifications were equally useful to predict survival between low/intermediate and high grade MEC. In contrast to previous studies $(5,6,7,8,9,11)$, all three systems failed to show a statistically significant difference in the survival when patients with low and intermediate grade MECs were compared.

The difficulty in scoring histopathological features may have contributed to the grades obtained, such as, anaplasia, as most of the MEC did not show anaplasia throughout the tumour. Only the ones which showed anaplasia in more than 50\% of the tumour were given the required score. Most tumours were not processed in their entirety and hence areas with perineural invasion or necrosis may have been missed. The inability to separate mitotic figures in prophase from apoptotic bodies and the low sample size may have also contributed to the non significant results observed between low and intermediate grade MEC in this study. These difficulties may have resulted in intermediate grade MEC being given a low grade. However no such difficulty was observed when grading high grade MEC.

In addition to survival, it was also possible to comment on the recurrence rate, as statistically significant number of high grade MEC presented with recurrence compared to low/intermediate grade MEC.

\section{Conclusion}

Histopathological grade carries a high prognostic significance, when MEC is graded according to the AFIP and Modified Healey system. The Brandwein system was found to be unsuitable to predict survival and prognosis of patients with MEC in this study. As in rare occasions low grade MEC also behave in an aggressive manner, further studies using gene expression and molecular markers may be required to accurately predict the behaviour of MEC.

\section{References}

1. Tilakaratne WM, Jayasooriya PR, Tennakoon TMPB, Saku T. Epithelial salivary tumours in Sri Lanka: A retrospective study of 713 cases. Oral Surgery Oral Medicine Oral Pathology Oral radiology and Endodontics 2009; 108: 90-98.

2. Rapidis AD, Givalos N, Gakiopoulou N, Stavrianos SD et al., Mucoepidermoid carcinoma of the salivary glands. Review of the literature and clinicopathological analysis of 18 patients. Oral Oncology 2007; 43: 130-136.

3. Seethala R. An update on grading of salivary gland tumours. Head and Neck Pathology 2009; 3: 69-77. www.uscap.org/site /98th/pdf/companion 14h02.pdf

4. Ellis GL, Auclair PL. Mucoepidermoid carcinoma. In Atlas of Tumour Pathology: Tumours of the Salivary glands, 3rd series, fascicle 17. Washington DC: Armed Forces Institute of Pathology 1996; 155-175.

5. Auclair PL, Goode RK, Ellis G. Mucoepi 
dermoid carcinoma of intraoral salivary glands: evaluation and application of grading criteria in 143 cases. Cancer 1992; 69: 2021-2030.

6. Goode RK, Auclair PL, Ellis GL. Mucoepidermoid carcinoma of major salivary glands: Clinical and histologic analysis of 234 cases with evaluation of grading criteria. Cancer 1998; 82: 1217-24.

7. Brandwein MS, Ivanov K, Wallance DI, Hille JJ, Wand B, Fahmy A, Bodian C, Urekin ML, Gnepp DR, Huvos A, Lumerman H, Mills SE. Mucoepidermoid carcinoma: A clinicopathologic study of 80 patients with special reference to histological grading. American Journal of Surgical Pathology 2001; 25: 835-845.

8. Hicks MJ, El-Naggar AK, Flaitz CM, Luna MA, Batsakis JG. Histologic grading of Mucoepidermoid carcinoma of major salivary glands in prognosis and survival: a clinicopathological and flow cytometric investigation. Head and Neck: 1995; 17: 89-95.

9. Healey WV, Perzin KH, Smith L. Mucoepidermoid carcinoma of salivary gland origin. Cancer 1970; 26: 368- 388.

10. Eveson JW, Auclair PL, Gnepp DR. In tumours of the salivary glands. Barnes EL, Eveson JW, Reichart P.Editors. World health Organization Classification of tumours: Pathology and Genetics. Head and Neck tumours: Lyons IARC press. 2005; 221-222.

11. Ozawa H, Tomita T, Sakamoto K, Tagawa T, Fuji R, Kanazi S, Ogawa K, Kameyama K, Fuji M. Mucoepidermoid carcinoma of Head and Neck. Japanese Journal of Clinical Oncology 2008; 38: 414-418. 